\title{
Predicting uptake of aquaculture technologies among smallholder fish farmers in Kenya
}

\section{Kevin Odhiambo Obiero ${ }^{1,2}$ (D) $\cdot$ Herwig Waidbacher ${ }^{1} \cdot$ Bryan Otieno Nyawanda $^{3}$. Jonathan Mbonge Munguti ${ }^{2}$. Julius Otieno Manyala ${ }^{4}$ - Boaz Kaunda-Arara ${ }^{4}$}

Received: 30 October 2018 / Accepted: 20 June 2019 /Published online: 22 August 2019

(C) The Author(s) 2019

\begin{abstract}
In Africa, many governments and development agencies have promoted aquaculture as a panacea for household food security, rural development, and poverty reduction. However, aquaculture production in the continent remains low despite significant investments in research and technology development. While numerous initiatives have been directed at technological innovation and transfer, their present scale of uptake is very slow and therefore inadequate to achieve transformational change envisaged in the 2030 Agenda for sustainable development. In this paper, we aim to (1) critically analyze the factors that influence fish farmer's perceptions, attitudes, and behaviors toward technology adoption; and (2) to determine the impacts of technology adoption on farmer's livelihoods. Primary data were collected using a selfadministered digitized questionnaire to 331 randomly selected farmers in Kenya. Multivariate logistic regression models were used to analyze data. Results revealed that variables including secondary education, diversified on-farm activities, farm size, production levels, attendance of extension training, ease of understanding, and ease of handling technologies were positive and significant predictors of aquaculture technology adoption. However, $30 \%$ of fish farmers were categorized as high adopters of novel aquaculture technologies, implying that there are gaps in technical skills hindering adoption of innovative technologies and best management practices. To facilitate learning and uptake of technologies and good practices by farmers, a range of aquaculture-related extension and communication materials, including posters, hard copy information leaflets and brochures of recipes in appropriate languages, short video presentations, and radio features, should be commissioned to support the smallholder farmers.
\end{abstract}

Keywords Aquaculture $\cdot$ Technology adoption $\cdot$ Sustainable livelihoods $\cdot$ Smallholder fish farmers $\cdot$ Kenya

Herwig Waidbacher

herwig.waidbacher@boku.ac.at

Kevin Odhiambo Obiero

kevobiero@gmail.com

Extended author information available on the last page of the article 


\section{Introduction}

Globally, aquaculture production has doubled every decade for the past 50 years (Bostock and Seixas 2015). As the world's fastest growing agrifood production sector, aquaculture has become the predominant source of fish protein, surpassing the amount of fish produced for direct human consumption from wild-caught fisheries (Golden et al. 2017; Toufique and Belton 2014). Aquaculture currently contributes $47 \%$ of global fish production and is growing rapidly, with 5.8\% annual growth rate during the period 2001-2016, but it no longer enjoys the high annual growth rates (average 8.8\%) experienced in the 1980s and 1990s (FAO 2016, 2018). With the rapid expansion of aquaculture in the past three decades, the industry has experienced boom and bust cycles and received negative reputation for its associated environmental impacts (Waite et al. 2014). Given the increasing scarcity of several aquaculture inputs, e.g., land, freshwater, and energy which are associated with significant environmental impacts, there have been calls for sustainable intensification (SI), broadly defined as "producing more using less" (Henriksson et al. 2018) to improve aquaculture's productivity and environmental performance (Waite et al. 2014).

The rapid growth of the aquaculture industry has been enabled through the expansion of aquaculture production areas (Oyinlola et al. 2018), intensification of production systems (Joffre et al. 2017), adoption of new technologies, and systematic improvement of existing technologies that brought control over husbandry and production processes (Kumar and Engle 2016; Henriksson et al. 2018; Kumar et al. 2018). Aquaculture offers great scope for technical innovation to further increase animal protein supply and resource efficiency (Waite et al. 2014). In the past 5 decades, technological advances in production and breeding systems, feeds and nutrition technology, vaccines, species and strain selection, reproductive control, mechanical aeration, and water exchange and non-technological innovations including improved regulatory frameworks, market, and certification standards, among others, have enabled the growth of aquaculture sector (Kumar and Engle 2016; Joffre et al. 2017). Recent studies indicate that investments in new production systems, management practices, and new products result in substantial benefits to producers and consumers (Kumar and Engle 2016; Kumar et al. 2018). However, there is still incoherent understanding of technological change in aquaculture development in Africa.

Although Africa has the fastest growing aquaculture industry with high biophysical potential, the sector has not yet significantly contributed to sustainable food supplies and economic development (Brummett et al. 2008; Waite et al. 2014). Aquaculture accounted for $17 \%$ of total fish production in Africa, while contributing a paltry $2.5 \%$ to global production (Chan et al., 2019; FAO 2017, 2018; Obiero et al. 2019a). Like the rest of SubSaharan Africa, aquaculture development in East Africa is constrained by lack of goodquality seed and feed, low technical capacity, poor market and value addition, inadequate extension services and materials, poor management of culture systems, low capacity in disease diagnostics and biosecurity, and increasing competition from cheaper imported fish products (Mwima et al. 2012; Rothuis et al. 2014; Kaminski et al. 2017). Feed is most often the largest cost item in aquaculture and, thus, offers opportunities for cost saving associated with reduced quality and performance. Most aquaculture production systems in East Africa use farm-made or supplementary feeds ranging from single ingredients (e.g., rice bran, wheat bran, and maize bran) to a mix of ingredients, cooked or raw, as moist and dry formulated feeds (Munguti et al., 2014; Amankwah et al. 2016). Larger aquaculture operators often depend on commercially manufactured feeds purchased from several 
small- or medium-sized feed mills in the region and in most cases switch to imported feed, which deliver a consistent performance. However, prices of imported feeds are extremely high, to the extent that many small-scale fish farmers in East Africa often abandon fish farming. Fish seeds are sourced from hatcheries which are owned by either the government or private farmers (Opiyo et al., 2018). The policy and legal framework for fish seed certification and mechanisms to monitor compliance to fish seed production, supply, and quality are weak and inadequate to guarantee high performance.

While new technologies and innovations are being developed to ensure high-quality and consistent supply of farmed fish to the markets, the impact and scalability of uptake is very slow and inadequate to achieve transformational change envisaged in the 2030 Agenda for sustainable development. In recent years, several studies have identified multiple factors that influence aquaculture technology adoption (Dey et al. 2010; Wetengere 2011; Kumar et al. 2018). However, Glover et al. (2016, p. 5) succinctly noted that "the technology adoption literature provides little insights into the scale or impacts of technological change in African agriculture, let alone the dynamics of these processes." Furthermore, the literature on the livelihood impacts of aquaculture technology adoption, especially in the context of smallholder households, is limited. In this study, we aimed to (1) analyze the factors that influence fish farmer's perceptions, attitudes, and behaviors toward aquaculture technology adoption and (2) determine the impacts of technology adoption on farmer's livelihoods. We grouped aquaculture technologies into five categories representing sustainable intensification, namely (a) culture systems, (b) fish breeding and genetics, (c) feeds and fish nutrition, (d) fish health and disease control, and (e) value addition techniques, post-harvest management, and marketing (Waite et al. 2014; Joffre et al. 2017).

The research is focused in Kenya, where the government introduced a large-scale aquaculture subsidy program under the Economic Stimulus Programme (ESP) implemented from 2009 to 2012 (Ole-Moiyoi 2017). The ESP focused on pond construction, fish feeds and fingerlings supply, post-harvest management, and human resource capacity building of fish farmers and associated institutions. Prior to the ESP project in 2008, there were only 4,742 fish farmers countrywide with 7,530 fish ponds occupying 271 ha. The number of farmers increased tremendously to 49,050, with an estimated 69,998 ponds occupying 2,063 ha at the peak of the subsidy program in 2012 (Nyandat and Owiti 2013). With supportive government policies and substantial public investments, aquaculture production in Kenya increased rapidly from less than 1000 tonnes in 2006 to 24,000 tonnes in the mid-2010s (Obiero et al. 2019b) including in regions of the country with little history of fish production or consumption (Ole-Moiyoi 2017). There is a total of 47 counties in Kenya which are geographical units envisioned by the 2010 Constitution of Kenya as the units of devolved government. Using data collected from 38 counties in 223 constituencies implementing fish farming in Kenya, Macharia and Kimani (2016) estimated a total of 32,000 fish farmers countrywide in 2015. The total area under fish ponds was 2,105 ha in 2013, but the area reduced to $\sim 1,808$ ha in the year 2015 because of decline in number of ponds from 69,194 to 60,277 in 2 years (Macharia and Kimani, 2015). Therefore, pond-based aquaculture production has registered depressed performance for the third consecutive year, with total fish output dropping by $34 \%$ from 18,656 tonnes in 2015 to 12,356 tonnes in 2017 (KNBS 2015, 2018). These high rates of decline in number of fish farmers, ponds, and production present a unique scenario that warrants further investigation. 


\section{Analytical framework for technology adoption}

In the agricultural sector, theoretical and practical approaches to promote adoption of new farming practices have been intensively studied (Kuehne et al. 2017). The adoption literature record attempts to organize and classify the factors influencing technology adoption and diffusion of agricultural practices (Feder and Umali 1993; Rogers 2003; Kuehne et al. 2017). Traditionally, theories dealing with decision-making processes have highlighted the role of extrinsic variables grouped into three categories: characteristics of the farmer, characteristics of the external environment, and characteristics of the innovation (Meijer et al. 2015). For the aquaculture sector, numerous empirical studies (Dey et al. 2010; Wetengere 2011; Ndah 2015; Amankwah et al. 2016; Amankwah et al. 2018) and a recent review by Kumar et al. (2018) identified several factors driving aquaculture technology adoption. Though not exhaustive, Kumar et al. (2018) identified five broad categories: (a) source of information, (b) characteristics of the technology, (c) economic factors, (d) farm characteristics, and (e) sociodemographic and institutional factors. However, there are still relatively few attempts to make predictions about adoption outcomes using these factors (Kuehne et al. 2017). Moreover, only a few studies have analyzed the factors influencing fish farmer's perceptions, attitudes, and behavior (Ndah et al. 2011; Wandji et al. 2012; Olaoye et al. 2016). In this study, we present and apply a modified analytical framework, showing the linkages and interaction between extrinsic variables and intrinsic variables in the decision-making process of technology adoption (Fig. 1).

Experts from diverse disciplines and backgrounds have paid close attention to the internal decision-making process that looks beyond the mere characteristics of farmer, environment, and technologies by including psychological and motivational factors in technology uptake (Meijer et al. 2015; McDonald et al. 2016). For example, Davis (1989) proposed the Technology Acceptance Model (TAM) as a causal model whereby user acceptance and usage of technologies is determined by two key attitudinal components or beliefs, i.e., the perceived usefulness (PU) and perceived ease of use (PEOU) of the technology. Perceived usefulness of a technology reflects the benefits a person believes that technology can bring to improving their work performance, whereas perceived ease of use reflects the effort required to adopt and use the technology (Davis 1989; Flett et al. 2004; McDonald et al. 2016). McDonald et al. (2016) demonstrated the substantial importance of both indicators to technology adoption decisions and proposed that future research, extension, and education programs should focus on the benefits and usability of key technologies and evaluate their scientific merit. Based on theoretical and empirical literature review, predictor variables influencing technology adoption are identified and summarized in Table 1. The choice of intrinsic variables was guided by questions used in previous studies to determine perceived usefulness (PU) and ease of use of agricultural technologies (Flett et al. 2004; McDonald et al. 2016).

\section{Materials and Methods}

\section{Study area and sample selection}

The study applied a cross-sectional survey design to collect data using a pre-tested structured questionnaire administered to randomly selected fish farmers in Kenya. The data was collected between July 2017 and February 2018 in 9 counties selected based on five criteria, namely (a) 




Fig. 1 Analytical framework showing the linkages and interaction between extrinsic variables (a-d) and intrinsic variables (e), and the influence of the intervening variable (f) in the decision-making process of aquacultural technologies and potential livelihood impacts of technology adoption (modified from Meijer et al. 2015; Kumar et al. 2018)

high concentrations of aquaculture activity in terms of number of ponds and fish farmers; (b) high production potential areas supported by the aquaculture subsidy program; (c) existing infrastructure for fish processing, marketing, and research; (d) adequate water resources; and (e) marketing potential based on proximity to densely populated towns. The selected counties were Homa Bay, Kakamega, Migori, Vihiga, Nandi, Kiambu, Kirinyaga, Nyeri, and Meru (Fig. 2).

To calculate the sample size for this study, we assumed a reduction in the number of fish farmers to be $10 \%$ based on observed trends, with a power of $80 \%$ and $95 \%$ confidence level using power one-proportion method in Stata 13 (StataCorp 2013). This resulted in 305 farmers but after adjusting for a $15 \%$ non-response rate, we needed 351 farmers distributed across the selected counties by the proportion of farmers in each county. A total of 331 respondents were interviewed in the study.

\section{Data collection instruments}

Farmers completed an interviewer-administered, digitized questionnaire conducted using Open Data Kit (ODK) suite, an open-source application installed on Android mobile phones (Tecno PhonePad 7 II Tablet). The electronic data capture replaces paper-based questionnaire forms and allows for in-built logical checks and skip patterns, thus enabling data to be 
Table 1 Predictor variables that influence farmers' decision to adopt new aquaculture technologies

\begin{tabular}{|c|c|c|}
\hline & Variables & Definition of variables \\
\hline & \multicolumn{2}{|l|}{ Farmer characteristics } \\
\hline 1. & Age & Age of farmer in years \\
\hline 2. & Gender & 1 if the farmer is male; 0 otherwise \\
\hline 3. & Education & Level of education of the farmer \\
\hline 4. & Experience & Years of fish farming experience of the farmer \\
\hline 5. & Occupation & 1 if full-time; 0 otherwise (part-time farmer) \\
\hline \multirow[t]{2}{*}{6.} & Household size & Number of family members \\
\hline & \multicolumn{2}{|l|}{ Farm characteristics } \\
\hline 7. & Diversified on-farm enterprises & 1 if the farmer is engaged in on-farm enterprise; 0 otherwise \\
\hline 8. & Land tenure arrangements & 1 if full-time owner; 0 otherwise (part owner) \\
\hline 9. & Fish farm size & Land area utilized for fish farming \\
\hline \multirow[t]{2}{*}{10.} & Production status (yield) & 1 if high production $\left(>1.5 \mathrm{~kg}\right.$ per $\left.\mathrm{m}^{2}\right) ; 0$ otherwise (low) \\
\hline & \multicolumn{2}{|c|}{ Sources of information/extension support } \\
\hline 11. & Attended extension training & 1 if the farmer has attended training; 0 otherwise \\
\hline 12. & Access to extension services & 1 if farmer paid to access extension service; 0 if otherwise \\
\hline 13. & Satisfaction levels with extension & 1 if the farmer is totally satisfied; 0 totally dissatisfied \\
\hline 14. & $\begin{array}{l}\text { Fish cluster/group membership } \\
\text { Economic characteristics }\end{array}$ & 1 if farmer belongs to a group; 0 otherwise \\
\hline \multirow[t]{2}{*}{15.} & Source of capital & 1 if farmers use personal savings; 0 if otherwise \\
\hline & \multicolumn{2}{|c|}{ Characteristics of the technology (perceived attitudes by farmers) } \\
\hline 16. & Important for farming needs & 1 if technologies are important; 0 otherwise \\
\hline 17. & Better than replacement & 1 if new technology is better than replacement; 0 otherwise \\
\hline 18. & Increase profits & 1 if technologies increase profits; 0 otherwise \\
\hline 19. & Increase Yield & 1 if technologies increase yield; 0 otherwise \\
\hline 20. & Saves time & 1 if technologies save time; 0 otherwise \\
\hline 21. & Ease of understanding & 1 if the technology is easy to understand; 0 otherwise \\
\hline 22. & Ease of handling & 1 if the technology is easy to handle; 0 otherwise \\
\hline
\end{tabular}

instantaneously uploaded to and stored securely in a password-protected online database (Hartung et al. 2010). The structured questionnaire solicited information on socioeconomic and demographic details, fish farm profile and production characteristics, sources of information and extension services, farmers' awareness and adoption of aquaculture technologies, economic viability, and livelihood impacts of aquaculture technologies.

\section{Data analysis}

Data were analyzed using Stata version 13 (Corp 2013) and IBM SPSS Statistics for Windows, version 22 (Corp 2013). Descriptive analyses were done by use of counts, means, median, percentages, standard deviation, and ranges. Composite scores were calculated for Likert scale ranked data for ease of interpretation. Adoption score was calculated using the following ranks: adoption $=0$ if the farmer reported awareness, interest, or decision to try different aquaculture technology components and adoption $=1$ if the farmer had tried or fully adopted the various components of sustainable aquaculture intensification. As for the attitudinal statements, agree and strongly agree were coded as 1 and the other three scales (strongly disagree, disagree, and neutral) as 0 . Inferential analyses were done using univariate and multivariate logistic regression models to identify the interaction effects of explanatory or independent variables on the dependent variable, i.e., the likelihood of technology adoption classified as high adopters and low adopters. Multivariate analysis included variables that were significant during univariate analysis but only one variable was picked among a group of 


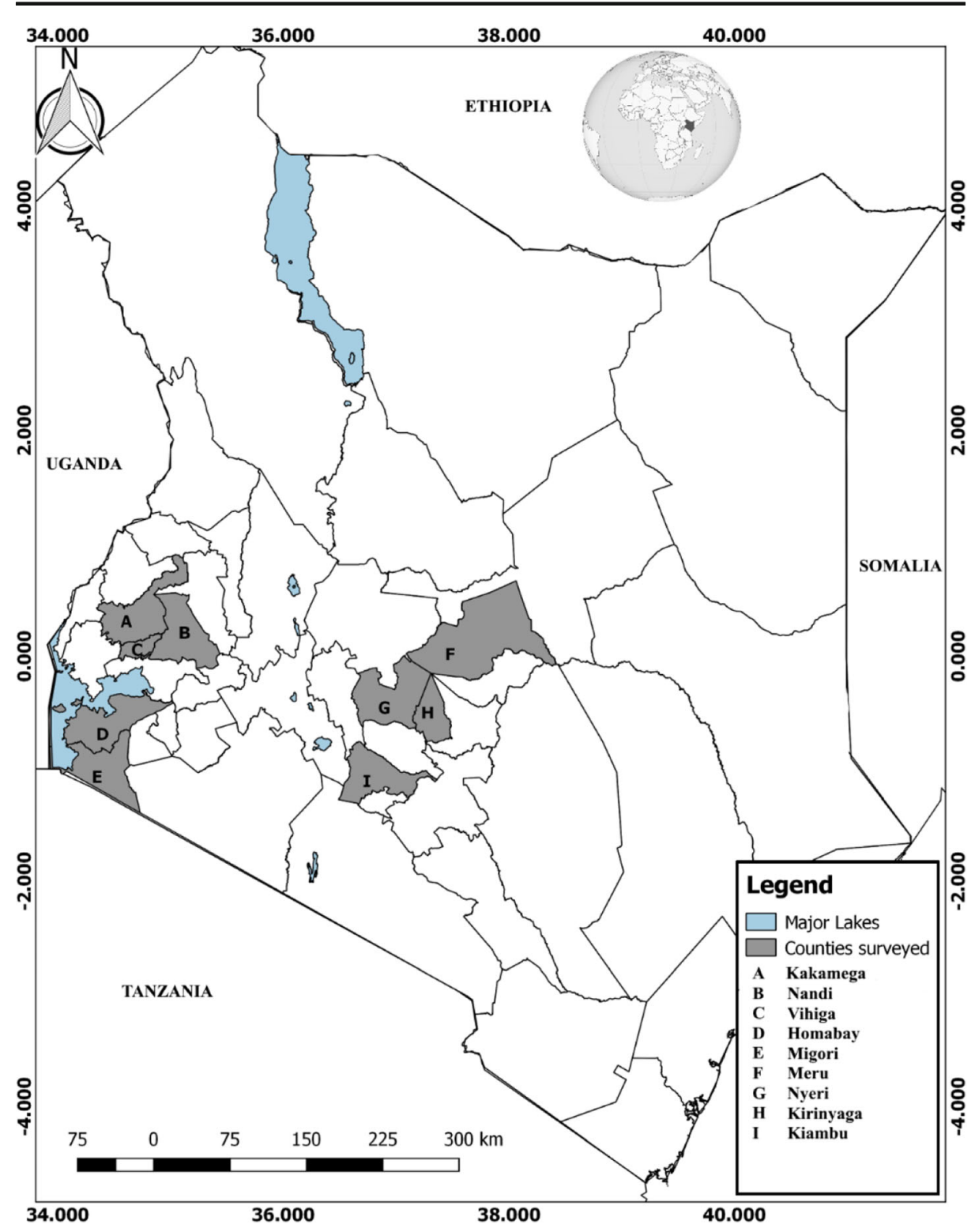

Fig. 2 Map of study areas showing selected counties for cross-sectional survey in Kenya

variables that were collinear. High adopters were farmers whose overall adoption score was above the mean adoption score of 4.7 (technically those who scored $\geq 5$ points). All the explanatory variables were entered into the multivariate logistic model directly and resultant adjusted odds ratios (OR) and their 95\% confidence interval (CI) reported (Stoltzfus 2011). A hierarchical cluster analysis (HCA) was used to explore underlying constructs in the survey data to identify distinct farmer adoption categories based on measures of attitudinal statements and motivations for adoption (Mattia et al. 2016). Additional discriminant and stepwise analyses were conducted on the resulting clusters to provide a subset of key variables to 
assess for significant differences between clusters. Statistical significance was considered when $\alpha=0.05$.

\section{Results}

\section{Socio-demographic characteristics}

Out of the 331 respondents, $258(78 \%)$ were males. The mean age of fish farmers was 50.8 years $(\mathrm{SD}=13.5)$, with the youngest being 19 years and the oldest 80 years. Overall, there were few women $(22 \%)$ and youths of age $\leq 35$ years $(13.3 \%)$. Seventy percent of farmers had attained secondary education and beyond. Almost equal proportions of fish farming households were composed of 6 to 10 members $(46.5 \%)$ and $45.9 \%$ for those with $\leq 5$ members. Most farmers $(84.6 \%)$ practice fish farming as an income-generating activity, out of which $59 \%$ have practiced fish farming for over 5 years. Apart from fish farming, $91.5 \%$ of farmers have diversified into other on-farm agricultural activities including livestock rearing (56\%), cereal production (45\%), horticulture (39\%), and industrial crop production (22\%) as a strategy to increase their income sources.

Eleven profiles were obtained through pooling five socio-demographic variables, i.e., age, gender, education, household size, and occupation to form a multivariate representation of the fish farming households. The higher the number of profiles $(n \geq 10)$, the greater the degree of homogeneity among fish farmers, and vice versa. Ten types of socio-demographic profiles were categorized as homogenous, constituting approximately $60 \%(n=195)$ of all sampled fish farmers while $41 \%(n=136)$ belonged to highly heterogeneous profiles, hence were lumped together in one profile. The largest profile $(11 \%)$ consisted of males aged $>50$ years who had attained secondary education/craft certificate (village polytechnics, vocational training institutes) and living in households with $>5$ members. Five profiles consisted of male farmers aged $<50$ years but with varying household sizes and education levels. Despite fish farming being male-dominated, two profiles were categorized as female-dominated, falling within the same age group ( $\leq 50$ years) with diverse household sizes and education levels.

\section{Farm production characteristics}

Close to three quarters (72.8\%) of farmers inherited the farmland from their family lineage while the rest purchased, leased, or rented the land for a specific period subject to payment of a fee or rent. The average agricultural farming household owns 5.4 acres of land with a standard deviation (SD) of 8.6 acres. The average land size utilized for fish farming is 0.21 ( $\mathrm{SD}=0.31$ ) acres $\left(\approx 850 \mathrm{~m}^{2}\right)$. The main reasons farmers venture into fish farming are to increase their incomes $(91 \%)$ and provide food for their household $(51 \%)$. The main sources of capital for initiating aquaculture enterprises is through borrowing from banks and microfinance institutions $(66 \%)$. Worth noting is that $41 \%$ of farmers had initiated fish farming activities between 2009 and 2013, mainly supported by the government's aquaculture subsidy program.

Most farmers (84\%) actively manage their ponds, with a few (11\%) having dormant or abandoned ponds. Over $79 \%$ of farmers use earthen pond with an average size of $300 \mathrm{~m}^{2}$ owned individually ( $\geq 80 \%$ ) for the culture of tilapia and catfish species. Twenty-four percent of farmers use liner ponds for culture purposes. The median number of tilapia and catfish fingerlings stocked by farmers is 1,000 (Inter-Quartile Range (IQR), 500-1,500) for each 
culture period that normally lasts an average of eight months. Sixty-six percent of farmers reported low fish production during their last production cycle. The main reasons attributed to the low fish production were lack of quality and affordable fish feeds $(40 \%)$, predation of fish (22\%), and lack of quality fingerlings (18\%).

\section{Advisory and extension services}

Over three quarters (77\%) of farmers participated in aquaculture advisory, extension, and training programs. The farmers attended or received a mean number of two trainings per year. The main organizations offering advisory and extension services include County Fisheries Departments (43\%) and non-governmental organizations or community-based organizations (31\%). The knowledge and skills acquired by farmers during extension training are related to pond fertilization and liming (81\%); pond design and construction (79\%); fish feed formulation, processing, and management (74\%); water quality management (71\%); and record keeping and enterprise budgeting (64\%). For the trained farmers, three quarters (76\%) reported they acquired new knowledge and skills that motivated them to adopt new aquaculture technologies and increase their yields and household incomes as well as create employment opportunities.

Farmers participating in extension programs preferred a mix of extension approaches for delivery of training services - 50\% preferred training and visit approach, $20 \%$ favored farmer group training, and 13\% liked "farmer to farmer" exchange visits to model farms. The four main extension methods used for disseminating aquaculture information include individual farm visits $(68 \%)$; mass media $(46 \%)$, e.g., radio and television; practical demonstration of technologies (37\%); and theoretical training (36\%). Most farmers (69\%) are members of a group or cooperative/association supporting their fish farming operations. The median number of years of membership to either a group or an association is 3 (IQR, 2-5), with the median number of members per group being 23 (IQR, 15-50), while the median number of meetings held yearly is 8 (IQR, 3-12). The key benefits enjoyed by members of groups or associations include training and skills development (62\%), linkages to extension providers (44\%), better access to markets (42\%), access to affordable finance and credit (35\%), and sourcing of quality fingerlings and feeds $(25 \%)$.

Across the five stages of technology adoption process, $62.9 \%$ of farmers are aware of new technologies while $28.7 \%$ are interested in adopting aquaculture technologies. On average, $26.3 \%$ of farmers are currently using supplementary or commercial fish feeds, $18.5 \%$ use breeding and genetic techniques, and $9.6 \%$ apply value addition and post-harvest loss reduction techniques. The main technologies fully adopted by farmers include use of hormonal sexreversed fingerlings $(62.3 \%)$, supplementary feeds $(60.4 \%)$, value addition techniques $(30.8 \%)$, commercial pellet feeds $(28.1 \%)$, complete starter feeds $(26.6 \%)$, use of liner ponds $(24.2 \%)$, integrated agriculture-aquaculture systems (19.6\%), and on-farm feed formulation (19.3\%). Few farmers have decided to try new technological innovations, but the adoption of modern culture systems, e.g., recirculation systems and aquaponic, is still extremely low (< $1 \%)$.

\section{Predicting aquaculture technology adoption process and behavior}

Several predictor variables were screened for analysis to show how they influence farmers' decision to adopt aquaculture technologies. The composite analysis shows that 99/331 (30\%) 
of farmers were categorized as high adopters. At the univariate level, 9/22 predictor variables were positively and significantly associated with increased aquaculture technology adoption. These included secondary education and above (odds ratio $[\mathrm{OR}]=4.46 ; 95 \%$ confidence interval $[\mathrm{CI}] 2.33-8.53)$, diversified on-farm agricultural activities $(\mathrm{OR}=3.86$; 95\% CI 1.14 $13.11)$, fish farm size $(\mathrm{OR}=3.39 ; 95 \% \mathrm{CI}, 1.14-10.04)$, production status $(\mathrm{OR}=2.02 ; 95 \% \mathrm{CI}$ $1.20-3.38)$, attendance of extension training $(\mathrm{OR}=4.15$; $95 \% \mathrm{CI} 1.98-8.70)$, and satisfaction with extension services $(\mathrm{OR}=2.21 ; 95 \% \mathrm{CI} 1.29-3.78)$. In addition, three technology-related variables based on farmer's perceived attitudes, i.e., "increase in yield" (OR $=2.34$; 95\% CI $1.09-5.00)$, "ease of understanding" (OR $=2.10$; 95\% CI 1.27-3.48), and "ease of handling" $(\mathrm{OR}=1.84 ; 95 \%$ CI 1.07-3.15) were significant predictors of higher adoption of aquaculture technologies (Table 2).

Conversely, four variables were negatively associated with aquaculture technology adoption, including age, occupation, household size, and whether a technology is better than the replacement (Table 2). At multivariate level, four variables remained significant positive predictors of higher adoption of aquaculture technologies, i.e., above secondary level education (adjusted odds ratio $[\mathrm{aOR}]=4.31,95 \%$ CI 2.14-8.67), fish farm size $(\mathrm{aOR}=3.74,95 \%$ CI 1.14-12.27), attendance of extension training ( $\mathrm{aOR}=3.25,95 \%$ CI 1.49-7.10), and ease of understanding of technology ( $\mathrm{aOR}=2.39,95 \% \mathrm{CI} 1.36-3.48)$. Based on farmers' attitudes and perceptions toward technology adoption, a high level of agreement was observed across all attitudinal statements with an average median value of 4 (IQR 4-5, Table 3. Four clusters were identified with the means of each cluster being significantly different from the other $(p<0.01)$. For clusters 1,2, and 4, the means for perceived usefulness of a technologies were higher than those for perceived ease of use of technologies, while for cluster 3, the means were similar and represented the largest number $(n=155)$ of farmers interested in adopting new or existing aquaculture technologies.

\section{Livelihood impacts of aquaculture technology adoption}

Over $80 \%$ of farmers agreed that adoption of aquaculture technologies is positively and significantly associated with increased livelihood outcomes, i.e., increased fish consumption $(\mathrm{OR}=4.57$; 95\% CI 1.36-15.38), increased incomes and profits $(\mathrm{OR}=5.40 ; 95 \%$ CI 1.88 15.50), wealth creation $(\mathrm{OR}=4.09 ; 95 \% \mathrm{CI} 2.38-7.01)$, and creation of employment opportunities ( $\mathrm{OR}=4.09$; 95\% CI 2.01-8.31) (Table 4). However, increased availability of fish in markets was positively associated but statistically insignificant $(\mathrm{OR}=2.18$; 95\% CI $0.93-5.11$ ). Farmers also reported that technology adoption is associated with an increase of $2-$ 5 times in their livelihood outcome indicators.

\section{Discussion}

Fish farming in Kenya is dominated by men possessing secondary education certificate with over 5 years of fish farming experience. There are huge gender and youth disparities, with women composing less than a quarter of fish farmers in Kenya. These findings agree with studies by Ole-Moiyoi (2017) and Amankwah (2016) revealing fish farming households are predominantly headed by males. This is probably based on strong cultural norms that typically look to male heads of households as decision-makers while placing most household chores and responsibilities in the hands of women. As elaborated by Ndanga et al. (2013), women's roles 


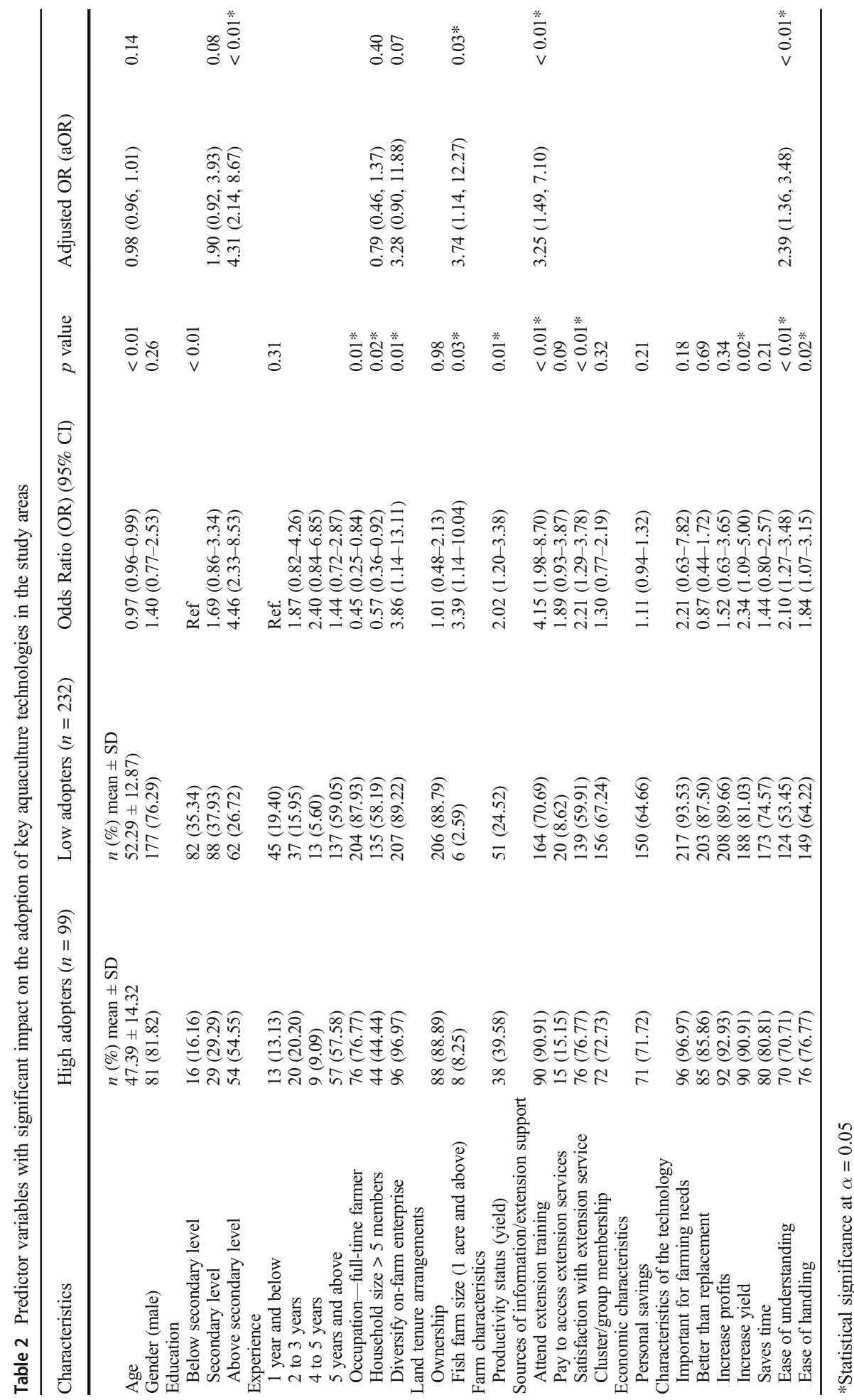


Table 3 Categories of fish farmers and comparisons between their technology characteristics

\begin{tabular}{|c|c|c|c|c|c|}
\hline Attitudinal statements & $\begin{array}{l}\text { Cluster } \\
1\end{array}$ & $\begin{array}{l}\text { Cluster } \\
2\end{array}$ & $\begin{array}{l}\text { Cluster } \\
3\end{array}$ & $\begin{array}{l}\text { Cluster } \\
4\end{array}$ & $\begin{array}{l}\text { Median } \\
\left(\mathrm{IQR}^{*}\right)\end{array}$ \\
\hline \multicolumn{6}{|l|}{ Perceived usefulness (PU) of technology } \\
\hline Is this technology important to your farming needs? & 4 & 5 & 4 & 5 & $4(4-5)$ \\
\hline Is this technology better than what it replaces? & 4 & 4 & 4 & 5 & $4(4-5)$ \\
\hline $\begin{array}{l}\text { Is this technology able to increase your financial } \\
\text { profits? }\end{array}$ & 4 & 5 & 4 & 5 & $4(4-5)$ \\
\hline $\begin{array}{l}\text { Is this technology able to increase production for } \\
\text { you? }\end{array}$ & 4 & 5 & 4 & 5 & $4(4-5)$ \\
\hline Is this technology able to save you time? & 3 & 4 & 4 & 5 & $4(4-5)$ \\
\hline \multicolumn{6}{|l|}{ Perceived ease of use (PEOU) } \\
\hline Is this technology easy for you to understand? & 3 & 2 & 4 & 4 & $4(4-5)$ \\
\hline Is this technology easy for you to use? & 3 & 3 & 4 & 4 & $4(4-5)$ \\
\hline Total $(n=331)$ & 72 & 56 & 155 & 46 & \\
\hline
\end{tabular}

The scaling system 1-5 is categorized in order of importance (i.e., means in ascending of importance)

*The interquartile range is equal to the difference between 25 th and 75 th percentiles, or between upper and lower quartiles

in aquaculture production activities are significant, but often under-recognized or "hidden" in aquaculture value chain analyses. Women's role is similarly masked by ownership of land and other production facilities frequently being formally or informally held by male household members (Kruijssen et al. 2018). The low uptake of aquaculture among women and especially the youth is a threat to the social sustainability of aquaculture (Obwanga and Lewo 2017).

The average age of a fish farmer in Kenya is 60 years, which is striking because the country's demographic is skewed toward the young people (UNDP 2018). Even though Kenya's youth (18-35 years) account for $35 \%$ of the population and $60 \%$ of the total labor force, only $10 \%$ are directly participating in the agricultural sector (British Council 2018). Recent trends indicate the youth population has opted to abandon agriculture in pursuit of white-collar job opportunities in urban centers (UNDP 2018). Some of the critical barriers hindering the participation of women and youth in the aquaculture sector are low literacy levels, lack of access to capital, inadequate land ownership and markets. For fish farming to be attractive to the youth, there is a need to change business strategy by investing in modern technologies. This is because younger farmers are more innovative and prefer to keep up with new technologies and have longer planning horizons (Koundouri et al. 2006). While farmers' age is negatively associated with technology adoption in the present study, there is no clear consensus on the effect of age on previous adoption decisions (Kumar et al. 2018). Age is often cited in the literature as influencing technology adoption, but since its direction of influence is inconsistent between studies, it can be excluded as an explanatory variable (Pannell et al. 2006; Kuehne et al. 2017).

Education is considered a key element for better employment opportunities. Kenya has made significant progress in recent years with primary education enrolment numbers now officially at $100 \%$ (British Council 2018). Education is positively and significantly correlated with aquaculture technology adoption (Pannell et al. 2006; Prokopy et al. 2008; Läpple et al. 2015; Ngoc et al. 2016). Well-educated farmers are able to access information and knowledge of production processes and a higher capacity to process and analyze new information (CofreBravo et al. 2018). Uaiene et al. (2009) reported that education gives farmers the ability to perceive, interpret, and respond to new information much faster than their less-educated 
Table 4 Potential impacts of aquaculture technology adoption on livelihood outcome indicators

\begin{tabular}{llllll}
\hline $\begin{array}{l}\text { Livelihood outcome } \\
\text { indicator }\end{array}$ & $\begin{array}{l}\text { High adopters } \\
n=99\end{array}$ & $\begin{array}{l}\text { Low adopters } \\
n=232\end{array}$ & Total positive impact & OR (95\% CI) & $p$ value \\
\hline $\begin{array}{l}n(\%) \\
\begin{array}{l}\text { Increased fish } \\
\text { consumption }\end{array}\end{array}$ & $\begin{array}{l}n(\%) \\
203(87.5)\end{array}$ & $\begin{array}{l}n(\%) \\
299(90.3)\end{array}$ & $4.57(1.36-15.38)$ & 0.01 \\
$\begin{array}{c}\text { Increased availability } \\
\text { of fish in markets }\end{array}$ & $92(92.9)$ & $199(85.7)$ & $291(87.9)$ & $2.18(0.93-5.11)$ & 0.06 \\
$\begin{array}{c}\text { Increased incomes and } \\
\text { profits }\end{array}$ & $95(96.0)$ & $189(81.5)$ & $284(85.8)$ & $5.40(1.88-15.50)$ & $<0.01$ \\
$\begin{array}{c}\text { Wealth creation, e.g., } \\
\text { ownership of } \\
\text { household assets }\end{array}$ & $77(77.8)$ & $107(46.2)$ & $184(55.6)$ & $4.09(2.38-7.01)$ & $<0.01$ \\
$\begin{array}{c}\text { Create employment } \\
\text { opportunities }\end{array}$ & $89(89.9)$ & $159(68.5)$ & $248(74.9)$ & $4.09(2.01-8.31)$ & $<0.01$ \\
\hline
\end{tabular}

counterparts. Amankwah et al. (2016) found that household heads in Kenya who had spent more years in school and operated fish farms for more than 5 years had high levels of technology adoption, which is vital for the sustainability of the sector.

The results indicate that large household size is negatively associated with technology adoption. In Kenya, smallholder agricultural families are usually large, with an average of seven members, out of which two are younger than 14 years of age (Rapsomanikis 2015). In contrast, Danso-Abbeam et al. (2018) reported that large households tend to have the free labor supply toward the adoption of an innovation than the smaller households. In addition, larger households have more ability to participate in extra activities as they divide their manpower into various activities. Therefore, it is expected that, all else being equal, the larger the household size, the greater the probability of participation in technology adoption (Suvedi et al. 2017).

Farm-specific characteristics, proxied by diversification of agricultural activities, farm size, and production status, had a highly significant and positive effect on aquaculture technology adoption. Farmers often diversify their activities as a risk management strategy to stabilize their incomes. The size of farms is often suggested as important in farm-based decisions on technology adoption and other agricultural activities (Kumar et al. 2018). Farmers with larger farms, it is often suggested, are more likely to innovate and adopt improved aquacultural technologies than those with smaller farms (Wetengere 2011; Bosma et al. 2012). The owners of large farms are usually wealthier and less risk averse to employ diversification strategies (Rapsomanikis 2015). However, while a high proportion of fish farmers in Kenya continue to actively manage their fishponds, their production volumes remain low, hence hindering adoption of novel technologies. The low production status is mainly caused by high cost of inputs, inadequate supply of quality and affordable fish feed and fingerlings, limited financial and credit facilities, predation and theft, lack of skilled workforce, water scarcity, and complex and expensive technologies, which are consistent with previous studies (Rothuis et al. 2011; Munguti et al. 2017; Obwanga and Lewo 2017).

Extension and advisory services play a major role in the promotion and adoption of sustainable aquaculture practices (Engle 2017; Kumar et al. 2018). A major factor for China's success in maintaining a highly productive aquaculture sector is the presence of a national extension system with well-trained and qualified staff offering widespread outreach to producers (Msangi and Batka 2015). In Kenya, several aquaculture extension programs have been 
launched (Ngugi and Manyala 2009), and access to advisory and extension support services is well established in the study areas. Farmer's attendance of extension training programs and their satisfaction with extension services were significantly associated with high adoption decisions. Generally, farmer's knowledge about new technologies depends on several characteristics, i.e., their existing skills and knowledge, their involvement in farmer groups, and their usage of farm advisors and on the relative advantage of the practice (Kuehne et al. 2017).

Frequent visits to farmers coupled with issuing of simple materials for reading and constant communication by extension agents positively influences adoption behavior for fish farming (Wetengere 2011; Joffre et al. 2017; Kumar et al. 2018; Ngugi et al. 2018). Amankwah et al. (2016) found that households receiving ten extension contacts per year have about $76 \%$ likelihood of purchasing large quantities of commercial pellets in Kenya. Therefore, extension service providers must devise optimum arrangements and appropriate technical specifications for public and private-sector extension support service for smallholders engaged in aquaculture. Based on these study results, extension approaches should contain an appropriate mix of practical demonstrations, Farmers' Field Schools (FFSs), and farmer-to-farmer exchange visits and methodologies that also maximize the participation of women (Faure et al. 2012). Misiko and Halm (2016) recommended using a mix or combination of extension delivery methods rather than concentrating on one as the most effective approach. Therefore, extension and advisory service provision not only promote the social sustainability of aquaculture program but also lead to increased farm productivity, incomes, and employment opportunities (Engle 2017).

The key training needs that farmers lack and where extension workers can focus their efforts are mainly on business skills, such as production planning, cost and revenue recording, and marketing, as well as support in accessing finance to ensure fish farmers and input suppliers are equipped to invest in their businesses and increase their income. When given a choice, individuals usually choose to interact and communicate with a group with similar beliefs, education, and social status (Kumar et al.,2018). Therefore, farmers' participation in groups exposes them to various information sources which enables them to analyze risks and benefits and take advantage of new innovations (Mignouna et al. 2011; Ghimire and Huang 2015; Suvedi et al. 2017). Some of the benefits accrued by members of groups/associations include linkages and access to training and extension providers, better access to markets for their selling products, access to affordable finance and credit facilities, affordable sourcing of fingerlings and quality feeds, construction of ponds, and provision of fish storage services.

The choice of aquaculture technologies and their adoption levels remain a focus of smallholder farmers to increase production, productivity, and farm incomes (Ngugi et al. 2018). The main aquaculture technologies ranked highly in this study were related to feed and seed production. Regarding feed production, the main technologies and innovations associated with increased incomes and profits include use of supplementary feeds, use of commercial pellet feeds, and use of complete starter feeds. Much of the aquafeeds used in Kenya are supplemental farm-made feeds either produced on-farm or by small-scale semicommercial feed manufacturers. Using socioeconomic survey data from 1000+ fish farming households in the Lake Victoria region, Ole-Moiyoi (2017) demonstrated that farmers using commercially formulated pellets realized yields of $321 \mathrm{~kg}$ pond $^{-1}$ year $^{-1}$, farmers using their own formulated pellets obtained yields of $276 \mathrm{~kg}_{\text {pond }}{ }^{-1}$ year ${ }^{-1}$, while those using "kitchen scraps" leftover from meals and food preparation obtained yields of $249 \mathrm{~kg}$ pond $^{-1}$ year $^{-1}$. However, the development of aquaculture has been greatly constrained by the ever-increasing costs of fishmeal and fish oil. To remedy this situation, researchers and feed manufacturers 
have made significant progress to identify alternative ingredients from plant-based and insectbased protein sources for use in fish diets to develop cost-effective feeds that provide adequate nutrition while concurrently reducing the use of traditional sources of protein (Irungu et al. 2018; Ngugi et al., 2017; Onsongo et al. 2018).

In terms of seed production, there exists three significant technologies and innovations used mainly in Kenya: (a) selective breeding to improve desirable traits in Nile tilapia and African catfish; (b) hormonal sex reversal to produce all-male tilapia fingerlings to control reproduction and improve marketability of Nile tilapia (Githukia et al. 2015; Nyonje et al. 2018); and (c) mass production of catfish fingerlings through artificial propagation using injections of pituitary hormones (Opiyo et al. 2017; Nyonje et al. 2018). Furthermore, Ole-Moiyoi (2017) reported that ponds containing monosex male tilapia reach higher yields $\left(343 \mathrm{~kg}_{\text {pond }}{ }^{-1}\right.$ year $\left.{ }^{-1}\right)$ much faster than fish reared in mixed-sex ponds $\left(275 \mathrm{~kg}_{\text {pond }}{ }^{-1}\right.$ year $\left.{ }^{-1}\right)$. However, hormone treatment has raised concerns because it may affect consumer acceptance of the fish, and hormone residues may damage water quality and biodiversity (Bink, 2019). Despite the widespread use of hormones in monosex aquaculture, they are likely to alter various body systems, and possibly influence the susceptibility of fish to diseases and opportunistic infections, and they can pollute the environment (Abo-Al-Ela et al. 2017). Therefore, further studies should be conducted to find alternative more safe ways to ensure all-male aquaculture production, based on the masculinizing effect of high temperatures, and other genetic improvements, involving the use of YY male breeders which give all-male progenies (Abo-AlEla 2018). Elsewhere, Henriksson et al. (2018) demonstrated that simple changes in fish farming technology and management practices could result in economic and environmental sustainability of aquaculture enterprises. To sum up, there is a need for adoption of a commercial-oriented approach focusing on investments to improve the productivity of existing smallholder aquaculture producers from the current average of $60-100 \mathrm{~kg} / \mathrm{pond}$ up to $250-350$ $\mathrm{kg} /$ pond through appropriate production technologies, proper management, and good-quality inputs (Ole-Moiyoi 2017).

The results show perceived usefulness and perceived ease of use are key indicators in determining technology adoption among smallholder farmers. For a technology to receive wider adoption, a significant number of farmers stated that it should be easy to understand, be easy to handle, and increase yield and incomes. In line with previous studies, perceived usefulness of technology had a greater relative influence on adoption and usage behavior of technologies than perceived ease of use of technology (Flett et al. 2004; McDonald et al. 2016). Fish farmers categorized as high adopters reported increased aquaculture production and productivity, increased household incomes, and improved fish consumption and business opportunities in aquaculture. However, only $30 \%$ of fish farmers have fully adopted various aquaculture technologies, implying there are still gaps in technical skills hampering adoption of innovative technologies and best management practices. There is a need for research and extension service providers to improve technical skills and practical knowledge of fish farmers through assistance to women and youth to initiate projects by increasing the funding of training and extension programs at national and county levels. Although not all technologies are associated with higher aquaculture productivity, this study reveals that the most promising technologies that can lead to increased profit margins include use of sex-reversed fingerlings, use of complete commercial feeds, and use of valued addition methods. Therefore, a range of aquaculture-related extension and communication materials, including posters, hard copy information leaflets and brochures of recipes in appropriate languages, short video presentations, and radio features, should be initiated to support the smallholder farmers. 
Acknowledgments Open access funding provided by University of Natural Resources and Life Sciences Vienna (BOKU). Special thanks go to the project coordinators for the APPEAR project "Strengthening Regional Capacity in Research and Training in Fisheries and Aquaculture for Improved Food Security and Livelihoods in Eastern Africa" for the logistical support during data collection.

Financial information This study was financially supported by the Austrian Agency for International Cooperation in Education and Research (OeAD-GmbH) under the Austrian Partnership Programme in Higher Education and Research for Development (APPEAR) (Grant Number 101, 2015-2018).

\section{Compliance with ethical standards}

Conflict of interest The authors declare that they have no conflict of interest.

Ethical statement This article does not contain any studies with animals performed by any of the authors.

Open Access This article is distributed under the terms of the Creative Commons Attribution 4.0 International License (http://creativecommons.org/licenses/by/4.0/), which permits unrestricted use, distribution, and reproduction in any medium, provided you give appropriate credit to the original author(s) and the source, provide a link to the Creative Commons license, and indicate if changes were made.

\section{References}

Abo-Al-Ela HG (2018) Hormones and fish monosex farming: a spotlight on immunity. Fish Shellfish Immun 72: 23-30. https://doi.org/10.1016/j.fsi.2017.10.038

Abo-Al-Ela HG, El-Nahas AF, Mahmoud S, Ibrahim EM (2017) The extent to which immunity, apoptosis and detoxification gene expression interact with 17 alpha-methyltestosterone. Fish Shellfish Immun 60:289-298. https://doi.org/10.1016/j.fsi.2016.11.057

Amankwah A (2016) Subsidies, aquaculture technology adoption and welfare impacts in Ghana and Kenya. PhD Dissertation, Purdue University, West Lafayette, Indiana

Amankwah A, Quagrainie KK, Preckel PV (2016) Demand for improved fish feed in the presence of a subsidy: a double hurdle application in Kenya. Agr Econ 47:633-643. https://doi.org/10.1080 $/ 13657305.2017 .1413689$

Amankwah A, Quagrainie KK, Preckel PV (2018) Impact of aquaculture feed technology on fish income and poverty in Kenya. Aquacult Econ Manag:1-21. https://doi.org/10.1111/agec.12261

Bosma RH, Nhan DK, Udo HMJ, Kaymak U (2012) Factors affecting farmers' adoption of integrated rice-fish farming systems in the Mekong Delta, Vietnam. Rev Aquacult 4:178-190. https://doi.org/10.1111/j.17535131.2012.01069.x

Bostock J, Seixas S (2015) Investing in the human capital of the aquatic food sector: AQUA-TNET and the road ahead. Aquacult Int 23(3):861-881. https://doi.org/10.1007/s10499-015-9915-6

British Council (2018) Youth employment in Kenya: literature review. https://www.britishcouncil.co. $\mathrm{ke} / \mathrm{sites} / \mathrm{default} / \mathrm{files} / \mathrm{ng}$ kenya_youth_employment_in_kenya.pdf. Accessed on 28 September 2018

Brummett RE, Lazard J, Moehl J (2008) African aquaculture: realizing the potential. Food Policy 33:371-385. https://doi.org/10.1016/j.foodpol.2008.01.005

Chan CY, Tran N, Pethiyagoda S, Crissman CC, Sulser TB, Phillips MJ (2019) Prospects and challenges of fish for food security in Africa. Global Food Security 20:17-25. https://doi.org/10.1016/j.gfs.2018.12.002

Cofre-Bravo G, Engler A, Klerkx L, Leiva-Bianchi M, Adasme-Berrios C, Caceres C (2018) Considering the farm workforce as part of farmers' innovative behaviour: a key factor in inclusive on-farm processes of technology and practice adoption. Exp Agr:1-15. https://doi.org/10.1017/S0014479718000315

Corp IBM (2013) IBM SPSS Statistics for Windows, Version 22.0. IBM Corp, Armonk, NY

Danso-Abbeam G, Bosiako JA, Ehiakpor DS, Mabe FN (2018) Adoption of improved maize variety among farm households in the northern region of Ghana. Cogent Econ Financ 109(1):1-14. https://doi.org/10.1080 /23322039.2017.1416896

Davis FD (1989) Perceived usefulness, perceived ease of use, and user acceptance. MIS Quart 13:319-339. https://doi.org/10.2307/249008

Dey MM, Paraguas FJ, Kambewa P, Pemsl DE (2010) The impact of integrated aquaculture-agriculture on smallscale farms in Southern Malawi. Agr Econ 41:67-79. https://doi.org/10.1111/j.1574-0862.2009.00426.x 
Engle CR (2017) The case for effective public funding of aquaculture research and extension. J World Aquacult Soc 48:851-853. https://doi.org/10.1111/jwas.12487

FAO (2016) The state of world fisheries and aquaculture 2016 - contributing to food security and nutrition for all. Food and Agriculture Organization of the United Nations, Rome, Italy

FAO (2017) Regional review on status and trends in aquaculture development in sub-Saharan Africa - 2015. FAO Fisheries and Aquaculture Circular No. 1135/4, Rome, Italy

FAO (2018) The state of world fisheries and aquaculture 2018 - meeting the sustainable development goals. Food and Agriculture Organization of the United Nations, Rome, Italy

Faure G, Desjeux Y, Gasselin P (2012) New challenges in agricultural advisory services from a research perspective: a literature review, synthesis and research agenda. J Agr Educ Ext 18:461-492. https://doi. org/10.1080/1389224X.2012.707063

Feder G, Umali D (1993) The adoption of agricultural innovations. a review. Technol Forecast Soc Chang 43: 215-239. https://doi.org/10.1016/0040-1625(93)90053-A

Flett R, Alpass F, Humphries S, Massey C, Morriss S, Long N (2004) The technology acceptance model and use of technology in New Zealand dairy farming. Agr Syst 80:199-211

Ghimire R, Huang WC (2015) Household wealth and adoption of improved maize varieties in Nepal: a doublehurdle approach. Food Security 7(6):1321-1335. https://doi.org/10.1007/s12571-015-0518-X

Githukia CM, Ogello EO, Kembenya EM, Achieng' AO, Obiero KO, Munguti JM (2015) Comparative growth performance of male monosex and mixed-sex tilapia (Oreochromis niloticus L.) reared in earthen ponds. Croat J Fish 73:20-25. https://doi.org/10.14798/73.1.788

Glover D, Sumberg J, Andersson JA (2016) The adoption problem; or why we still understand so little about technological change in African agriculture. Outlook Agr 45:3-6. https://doi.org/10.5367/oa.2016.0235

Golden CD, Seto KL, Dey MM, Chen OL (2017) Does aquaculture support the needs of nutritionally vulnerable nations? Front Mar Sci 4:1-7. https://doi.org/10.3389/fmars.2017.00159

Hartung C, Anokwa Y, Lerer A, Brunette W, Tseng C, Borriello G (2010) Open data kit: tools to build information services for developing regions. In: Dell'Osa P, Unwin T, Kleine D (eds) Proceedings of the $4^{\text {th }}$ ACM/IEEE International Conference on Information and Communication Technologies and Development, December 13-16, 2010, London, United Kingdom

Henriksson PJG, Belton B, Jahan KM, Rico A (2018) Measuring the potential for sustainable intensification of aquaculture in Bangladesh using life cycle assessment. Proc Natl Acad Sci:1-6. https://doi.org/10.1073 /pnas. 1716530115

Irungu FG, Mutungi CM, Faraj AK, Affognon H, Tanga C, Ekesi S, Nakimbugwe D, Fiaboe KKM (2018) Minerals content of extruded fish feeds containing cricket (Acheta domesticus) and black soldier fly larvae (Hermetia illucens) fractions. Int Aquat Res 10:101-113. https://doi.org/10.1007/s40071-018-0191-8

Joffre OM, Klerkx L, Dickson M, Verdegem M (2017) How is innovation in aquaculture conceptualized and managed? A systematic literature review and reflection framework to inform analysis and action. Aquaculture 470:129-148. https://doi.org/10.1016/j.aquaculture.2016.12.020

Kaminski AM, Genschick S, Kefi AS, Kruijssen F (2017) Commercialization and upgrading in the aquaculture value chain in Zambia. Aquaculture 493:355-364. https://doi.org/10.1016/j.aquaculture.2017.12.010

Kenya Bureau of National Statistics (KNBS) (2015) Economic survey 2015, Nairobi, Kenya

Kenya Bureau of National Statistics (KNBS) (2018) Economic survey 2018, Nairobi, Kenya

Koundouri P, Nauges C, Tzouvelekas V (2006) Technology adoption under production uncertainty: Theory and application to irrigation technology. Am J Agric Econ 88:657-670 https://www.jstor.org/stable/3697756

Kruijssen F, McDougal CL, van Asseldonk IJM (2018) Gender and aquaculture value chains: a review of key issues and implications for research. Aquaculture 493:328-337. https://doi.org/10.1016/j. aquaculture.2017.12.038

Kuehne G, Llewellyn R, Pannell DJ, Wilkinson R, Dolling P, Ouzman J, Ewing M (2017) Predicting farmer uptake of new agricultural practices: a tool for research, extension and policy. Agr Syst 156:115-125. https://doi.org/10.1016/j.agsy.2017.06.007

Kumar G, Engle CR (2016) Technological advances that led to growth of shrimp, salmon, and tilapia farming. Rev Fish Sci Aquac 24:136-152. https://doi.org/10.1080/23308249.2015.1112357

Kumar G, Engle C, Tucker C (2018) Factors driving aquaculture technology adoption. J World Aquacult Soc 49: 447-476. https://doi.org/10.1111/jwas. 12514

Läpple D, Renwick A, Thorne F (2015) Measuring and understanding the drivers of agricultural innovation: evidence from Ireland. Food Policy 51:1-8. https://doi.org/10.1016/j.foodpol.2014.11.003

Macharia S, Kimani A (2016) Kenya fish farming enterprise productivity capacity assessment and gap analysis report. State Department of Fisheries and Blue Economy, Nairobi, Kenya

Mattia CM, Lovell ST, Davis A (2016) Identifying barriers and motivators for adoption of multifunctional perennial cropping systems by landowners in the Upper Sangamon River Watershed, Illinois. Agroforest Syst 92:1-15. https://doi.org/10.1007/s10457-016-0053-6 
McDonald R, Heanue K, Pierce K, Horan B (2016) Factors influencing new entrant dairy farmer's decisionmaking process around technology adoption. J Agr Educ Ext 22:163-177. https://doi.org/10.1080/1389224 X.2015.1026364

Meijer SS, Catacutan D, Ajayi OC, Sileshi GW (2015) The role of knowledge, attitudes and perceptions in the uptake of agricultural and agroforestry innovations among smallholder farmers in sub- Saharan Africa. Int J Agr Sustain 13:40-54. https://doi.org/10.1080/14735903.2014.912493

Mignouna DB, Manyong VM, Mutabazi KDS, Senkondo EM (2011) Determinants of adopting imazapyrresistant maize for Striga control in Western Kenya: a double-hurdle approach. J Dev Agric Econ 3:572-580 http://www.academicjournals.org/JDAE

Misiko M, Halm E (2016) ABCs of diversifying information resources among rice smallholders of Ghana. J Agr Educ Ext 22:271-289. https://doi.org/10.1080/1389224X.2015.1038281

Msangi S, Batka M (2015) The rise of aquaculture: the role of fish in global food security. In: Fan S (ed) 20142015 Global Food Policy Report. International Food Policy Research Institute, Washington, DC, pp 61-72

Munguti JM, Obiero KO, Orina PS, Mwaluma J, Mirera D, Ochiewo J, Kairo J, Njiru MJ (eds) (2017) State of aquaculture in Kenya ( $1^{\text {st }}$ ed). WestLink Services Limited, Nairobi, Kenya

Mwima H, Monor GV, Mbilinyi HG, Rathacharen S, Omanyi PB, Katonda KI (2012) Regional assessment of fisheries issues, challenges and opportunities for Eastern Africa region. African Union. Interafrican Bureau for Animal Resources, Nairobi, Kenya

Ndah HT (2015) Adoption and adaptation of innovations - assessing the diffusion of selected agricultural innovations in Africa. PhD Dissertation, Humboldt-University of Berlin. https://doi.org/10.13140/2.1.2452.9285

Ndah HT, Knierim A, Ndambi OA (2011) Fish pond aquaculture in Cameroon: a field survey of determinants for farmers' adoption behaviour. J Agr Educ Ext 17:309-323. https://doi.org/10.1080/1389224X.2011.576578

Ndanga LZB, Quagrainie KK, Dennis JH (2013) Economically feasible options for increased women participation in Kenyan aquaculture value chain. Aquaculture 415:183-190. https://doi.org/10.1016/j. aquaculture.2013.08.012

Ngoc PTA, Meuwissen MPM, Le TC, Bosma RH, Verreth J, Lansink AO (2016) Adoption of recirculating aquaculture systems in large pangasius farms: a choice experiment. Aquaculture 460:90-97. https://doi. org/10.1016/j.aquaculture.2016.03.055

Ngugi CC, Fitzsimmons K, Manyala J, Bundi JM, Kimotho AN, Amadiva JM, Ndogoni JN, Munguti J (2018) Assessment of growth performance of monosex Nile tilapia (Oreochromis niloticus) in cages using low-cost, locally produced supplemental feeds and training fish farmers on best management practices in Kenya. Project Report. Sustainable Feed Technology and Nutrient Input Systems/SFT/13SFT06AU

Nyandat B, Owiti G (2013) Aquaculture needs assessment mission report. Report/Rapport: SF-FAO/2013/24. September/Septembre 2013. FAO-SmartFish Programme of the Indian Ocean Commission, Ebene, Mauritius

Nyonje BM, Opiyo MA, Orina PS, Abwao J, Wainaina M, Charo-Karisa H (2018) Current status of freshwater fish hatcheries, broodstock management and fingerling production in the Kenya aquaculture sector. Livest Res Rural Dev 30, Article \#6. Retrieved August 1, 2018, from http://www.lrrd.org/lrrd30/1/mary30006.html

Obiero K, Meulenbroek P, Drexler S, Dagne A, Akoll P, Odong R, Kaunda-Arara B, Waidbacher H (2019a) The contribution of fish to food and nutrition security in Eastern Africa: emerging trends and future outlooks. Sustainability 11:1636. https://doi.org/10.3390/su11061636

Obiero K, Cai J, Abila R, Ajayi O (2019b) Kenya: high aquaculture growth needed to improve food security and nutrition, Rome, Italy http://www.fao.org/3/ca4693en/ca4693en.pdf

Obwanga B, Lewo MR (2017) From aid to responsible trade: driving competitive aquaculture sector development in Kenya; Quick scan of robustness, reliability and resilience of the aquaculture sector. Wageningen University and Research, Report 2017-092 3R Kenya

Olaoye OJ, Ezeri GNO, Akegbejo-Samsons Y, Awotunde JM, Ojebiyi WG (2016) Dynamics of the adoption of improved aquaculture technologies among fish farmers in Lagos State, Nigeria. Croat J Fish 74:56-70. https://doi.org/10.1515/cjf-2016-0012

Ole-Moiyoi LK (2017) Fishing for answers: can aquaculture transform food security in rural Kenya? PhD Dissertation. Standford University, Stanford

Onsongo VO, Osuga IM, Gachuiri CK, Wachira AM, Miano DM, Tanga CM, Ekesi S, Nakimbugwe D, Fiaboe KKM (2018) Insects for income generation through animal feed: effect of dietary peplacement of soybean and fish meal with black soldier fly meal on broiler growth and economic performance. J Econ Entomol 111: 1966-1973. https://doi.org/10.1093/jee/toy118

Opiyo MA, Orina P, Charo-Karisa H (2017) Fecundity, growth parameters and survival rate of three African catfish (Clarias gariepinus) strains under hatchery condition. J Aquacult Eng Fish Res 3:75-81. https://oi. org/10.3153/JAEFR17010 
Opiyo MA, Marijani E, Muendo P, Odede R, Leschen W, Charo-Karisa H (2018) A review of aquaculture production and health management practices of farmed fish in Kenya. Int J Vet Sci Med 6:141-148. https://doi.org/10.1016/j.ijvsm.2018.07.001

Oyinlola MA, Reygondeau G, Wabnitz CCC, Troell M, Cheung WWL (2018) Global estimation of areas with suitable environmental conditions for mariculture species. PLoS ONE 13:1-19. https://doi.org/10.1371 /journal.pone.0191086

Pannell DJ, Marshall GR, Barr NF, Curtis A (2006) Understanding and promoting adoption of conservation practices by rural landholders. Aust J Exp Agr 46:1407-1424. https://doi.org/10.1071/EA05037

Prokopy LS, Floress K, Klotthor-Weinkauf D, Baumgart-Getz A (2008) Determinants of agricultural best management practice adoption: evidence from the literature. J Soil Water Conserv 63:300-311. https://doi. org/10.2489/jswc.63.5.300

Rapsomanikis G (2015) The economic lives of smallholder farmers. An analysis based on household data from nine countries. Food and Agriculture Organization of the United Nations, Rome, Italy http://www.fao.org/3 /a-i5251e.pdf

Rogers EM (2003) Diffusion of innovations, 5th edn. Free Press, New York

Rothuis A, Duijn AP, van Rijsingen J, van der Pijl W, Rurangwa E (2011) Business opportunities for aquaculture in Kenya: with special reference to food security. LEI report 2011-067/IMARES report C131/11. Wageningen UR, Wageningen, p 2011

Rothuis A, Turenhout M, van Duijn A, Roem A, Rarangwa E, Katunzi E, Shoko AP, Kabagambe JB (2014) Aquaculture in East Africa; a regional approach. Wageningen UR (University and Research Centre), LEI Report IMARES C153/14| LEI 14-120. 54 pp.

StataCorp (2013) Stata Statistical Software: Release 13. StataCorp LP, College Station, TX

Stoltzfus JC (2011) Logistic regression: a brief primer. Acad Emerg Med 18:1099-1104. https://doi.org/10.1111 j.1553-2712.2011.01185.x

Suvedi M, Ghimire R, Kaplowitz M (2017) Farmers' participation in extension programs and technology adoption in rural Nepal: a logistic regression analysis. J Agr Educ Ext 23:351-371. https://doi. org/10.1080/1389224X.2017.1323653

Toufique KA, Belton B (2014) Is aquaculture pro-poor? Empirical evidence of impacts on fish consumption in Bangladesh. World Dev 64:609-620. https://doi.org/10.1016/j.worlddev.2014.06.035

Uaiene RN, Arndt C, Masters WA (2009) Determinants of agricultural technology adoption in Mozambique, Discussion Paper No. 67E, Ministry of Planning and Development, Republic of Mozambique

UNDP (2018) Cultivating youth entrepreneurship through agribusiness. http://www.ke.undp. org/content/kenya/en/home/ourwork/inecgr/successstories/cultivating-youth-entrepreneurship-throughagribusiness/. Accessed on 20 Sept 2018

Waite R, Beveridge M, Brummett RE, Castine S, Chaiyawannakarn N, Kaushik S, Mungkung R, Nawapakpilai S, Phillips M (2014) Improving productivity and environmental performance of aquaculture. Working Paper, Installment 5 of the Creating a Sustainable Future. World Resources Institute, Washington, DC

Wandji DN, Pouomogne V, Binam JN, Nouaga RY (2012) Farmer's perception and adoption of new aquaculture technologies in the Western Highlands of Cameroon. Tropicultura 30:180-184

Wetengere K (2011) Socio-economic factors critical for intensification of fish farming technology. A case of selected villages in Morogoro and Dar es Salaam regions, Tanzania. Aquacult Int 19:33-49. https://oi. org/10.1007/s10499-010-9339-2

Publisher's note Springer Nature remains neutral with regard to jurisdictional claims in published maps and institutional affiliations.

\section{Affiliations}

\section{Kevin Odhiambo Obiero ${ }^{1,2} \cdot$ Herwig Waidbacher ${ }^{1} \cdot$ Bryan Otieno Nyawanda $^{3} \cdot$ Jona- $^{-}$ than Mbonge Munguti ${ }^{2}$ - Julius Otieno Manyala ${ }^{4}$ Boaz Kaunda-Arara ${ }^{4}$}

1 University of Natural Resources and Life Sciences, Gregor-Mendel-Straße, 33 Vienna, Austria

2 Kenya Marine and Fisheries Research Institute (KMFRI), P.O. Box 451, Sagana, Kenya

3 Kenya Medical Research Institute (KEMRI), P.O. Box 1578, Kisumu, Kenya

4 Department of Fisheries and Aquatic Sciences, University of Eldoret, P.O. Box 1125, Eldoret, Kenya 